Guest Editorial, part of a Special Feature on Do we need new management paradigms to achieve sustainability in tropical forests?

\title{
Sustainable Forest Management in the Tropics: Is Everything in Order but the Patient Still Dying?
}

\author{
$\underline{\text { Robert Nasi }}^{1}$ and Peter G. H. Frost ${ }^{2}$
}

Key Words: sustainable forest management; tropical forests

\section{INTRODUCTION}

Tropical forests are under unprecedented pressure for conversion to pastoral and agricultural land or to plantations (including for biofuel production) and from the supply and extraction of forest goods and services, including timber and bushmeat (Kant 2004, Gardner et al. 2009). To preserve them, much effort has gone into setting up and managing a network of protected areas because, for various constituencies, conservation is best served by outright protection (Bowles et al. 1998), occasionally after initial extraction of valuable species (Rice et al. 1997). Others, however, see this as an ultimately limited option (Wood 1995, Lugo 1999, Pearce et al. 2003, Gardner et al. 2009). They argue the need to include sustainable forest management, balancing productivity and offtake with efforts to conserve biodiversity, maintain vital forest functions, and continue supplying various social and economic benefits, across various scales.

The principles underpinning forestry management have shifted over time. The initial focus on achieving sustained production of a single commodity, almost always timber (sustained-yield forestry, SYF), served its purpose for a long time (Steen 1984). Nevertheless, SYF proved inadequate both conceptually and practically in satisfying either existing societal demands on forests (e.g., sustaining local livelihoods) or emerging ones (e.g., recreation, ecosystem service provision). Forests produce much more than just timber, and the interests at stake extend beyond those of logging companies, timber merchants, silvicultural managers, or researchers (Michon et al. 2007). Operationally, the paradigm of optimal harvesting of a species, on the assumption that its population is reasonably stable and will return to equilibrium if harvested appropriately, is too restrictive (see also Hughes et al. (2005) in the context of marine resources). A more realistic approach is one in which many different outcomes are possible depending on how harvesting interacts with other drivers and disturbances, each with characteristic scale (local, national, global), type (anthropogenic, natural), recurrence interval (seasonal, erratic, yearly, or centennial), and intensity (mild, severe).

New societal demands on forests derived from the sustainable development discourse pushed the SYF paradigm further aside and led to one based on the sustained production of multiple goods and services (multiple-use forestry, MUF). This was soon extended to include provisions for maintaining future options and not damaging other ecosystems (sustainable forest management, SFM; United Nations 1992). This was given further support through the introduction of certification, designed to assure consumers that the products being purchased were being produced sustainably, equitably, and with appropriate management (Upton and Bass 1995). The limited success of MUF and SFM (Gong 2002, Hammond and Zagt 2006), seen against the backdrop of ongoing tropical deforestation, led in turn to the need to look beyond the forests and to consider the integrated management of land, water, and living resources. This approach, variously called "the ecosystem approach" or "integrated natural resource management (INRM)," was designed to achieve both conservation and sustainable use in an equitable way at the landscape level. At each stage, unfortunately, management has become more complicated, forcing us to recognize complex dynamics, with their attendant shifts and thresholds, 
inherent uncertainties, and the combined influence of both social and ecological forces on the outcomes.

There is a growing portfolio of (partial) successes in managing tropical forests for production. These include managed timber concessions in Latin America, Africa, and Southeast Asia (see Amsallen et al. 2004 or Durst et al. 2005); joint forest management in India (see Ravindranath and Sudha 2004); community-based forestry management in Africa, south Asia, and Central America (Alden Wily 2000, Agrawal and Ostrom 2001, Poffenberger 2001, Bray et al. 2008); and partnerships between environmental NGOs and logging companies to manage or conserve wildlife in various tropical countries (Nasi et al. 2008). Providing direct incentives to local people, usually as some form of payment for environmental service (PES), is increasingly being tried. These may ultimately be more viable than indirect approaches, such as integrated conservation and development projects (Wunder 2006), provided those who benefit from such services can be induced to pay for them (Wunder et al. 2008).

At the same time, one cannot help notice that forest management methods and prescriptions have only evolved marginally from the beginning of industrialization. Although new powerful tools such as GIS and remote-sensing imagery are now being used, and reduced-impact logging guidelines have been proposed almost everywhere in the tropics, the basic tenets of forest management have not really changed and are still based largely on European models "exported" to the tropics in the 1950s. Even with progressive approaches such as MUF or SFM, the multidimensional aspect of tropical forest management is still too often defined by specialists from other regions and cultures (Michon et al. 2007). Beyond timber, soil erosion, biodiversity, and carbon-the focus of much conventional forest management - there are also "domestic" forests, visited daily, harvested, and reshaped by farmers. These make up much of the forest matrix in the tropics but, too often, they are overlooked by managers. Truly integrated forest management at the landscape level and beyond requires bringing these forests into the management framework.

This special feature "Do we need new management paradigms to achieve sustainability in tropical forests?" builds on 14 contributions covering various aspects of tropical forest management. It reflects a growing sense that, whereas we have many technical prescriptions to address particular symptoms of the disease of tropical deforestation and forest degradation, perhaps we have not yet combined them effectively into cures of the underlying causes. Maybe even the aim and achievability of the treatments themselves need questioning. Is sustainable forest management - the gold-standard test of responsible forestry-actually achievable? What do we mean by "sustainability?" Is the triple bottom line of people, planet, and profits -optimal social, environmental, and economic performance-concurrently attainable, or do we have to accept triage in places, trading off the ideal in one place to make progress elsewhere?

\section{HOW WELL PROTECTED AND/OR MANAGED ARE TROPICAL FORESTS NOWADAYS?}

The statutorily protected area (International Union for the Conservation of Nature (IUCN) categories I-IV) in tropical and subtropical realms, estimated at about 1.9 million $\mathrm{km}^{2}$ (Schmitt et al. 2009), has more than doubled over the past decade. Expenditure on protection has no doubt increased also, although reliable data are hard to find. To protect these areas effectively would entail considerable direct costs to most developing countries (Wilkie et al. 2001). The opportunity costs, in terms of revenue foregone both from harvesting and from investments in other national development areas, are probably even greater. Even then, the effectiveness of these areas in protecting biodiversity is limited. For example, in the Amazon, the large area currently protected only encompasses the ranges of about $20 \%$ of the mammal species. Once Brazil's Amazon Region Protected Areas (ARPA) project is fully implemented, the area receiving statutory protection will increase to nearly 2.36 million $\mathrm{km}^{2}$, or $46 \%$ of the Brazilian Amazon (Azevedo-Ramos et al. 2006), but will only encompass about $30 \%$ of the ranges of mammal species. Even with a better integrated network covering neighboring countries, many species would not be fully protected (Azevedo-Ramos et al. 2006). The problem is global. The recent growth of the global protected-area network has not been planned or managed to maximize the overall conservation of biodiversity (Rodrigues et al. 2004). Many areas with outstandingly high conservation value are either unprotected or receive limited protection and are under serious threat. Is the prospect of significantly expanding the network feasible? 
Strict preservation, in which local people are excluded or prevented from harvesting forest products, not only fosters resentment against conservation, but also diminishes indigenous knowledge that could contribute to ecosystem management (Laumonier et al. 2008). It seems more realistic to work with current land users who have managed this land for a long time (Robichaud et al. 2009), at least in some areas, than to expect many new reserves to be set up. New reserves would likely cause some displacement of local people, or place curbs on their activities, thereby creating more people-conservation conflicts. For tropical developing countries, a more viable option could be multipurpose management, including ongoing use of these forests by local people. Rather than being induced or pressured into abandoning their forest heritage, rural communities should be actively involved in managing tropical forests productively (Wood 1995, Michon et al. 2007). As local perceptions do not always accord with conventional scientific understanding, this is something that requires discussion and trade-off (López-Hoffman et al. 2006).

Just as the area of protected tropical forests has increased, so too has the area of tropical forests under formal management, from less than 1 million ha in 1988 (Poore et al. 1989) to about 36 million ha in 2005 (International Tropical Timber Organization (ITTO) 2006). Tropical forests and plantations certified under the Forest Stewardship Council (FSC) standards have increased from less than 0.5 million ha in 1998 to 17.87 million ha in 2009 , which is $15.3 \%$ of the total area certified by the FSC globally (FSC 2009). Within the tropics, almost $82 \%$ of the certified area is natural forest; the balance consists of plantations (Frank Katto, FSC, personal communication, 10 November 2009).

Yet, despite considerable investments and progress in topical forest management, the results in terms of changed silvicultural and land-use practices have been modest (Wunder 2006 and references therein). The original tenets of forest management, introduced to the tropics in the 1950s and based largely on European experiences, have not really changed with the times and different circumstances under which forests are now managed. Sustainedyield harvesting remains the norm, maximizing yield within the imposed constraints of a minimum cutting diameter for the harvested species and a minimum rotation period among the harvested sections of forest, all across multiple cutting cycles.

\section{IS SUSTAINABLE FOREST MANAGEMENT ACHIEVABLE?}

Apart from the question of just what is "sustainable forest management," whether any such management is really sustainable is yet to be determined, given the long timeframes involved in natural forest dynamics. The evidence from some regions, such as the humid forests of Central Africa, where certification is expanding, suggests not. Current levels of extraction of the main timber species are probably not economically sustainable, as the timber volumes of commercially important species are unlikely to recover within a cutting cycle. The volumes extracted would need to be reduced by between a quarter and a half to be sustainable (Karsenty and Gourlet-Fleury 2006). Similar concerns about the level of offtake needed to produce a sustainable yield, and the often lower level needed to be ecologically sustainable as well, have been expressed about other tropical forest systems, e.g., mangroves (López-Hoffman at al. 2006) and ipê (Tabebuia spp.; Schulze et al. 2008). The converse also applies: prescribed logging intensities may be too low to create the conditions for the regeneration of many important commercial species that currently support much of the timber industry. This creates a paradox, in which the intensity of logging of these species is too high, but the overall logging intensity is too low to create the kind of disturbance regime needed for the regeneration of these preferred species (Fredricksen and Putz 2003, Karsenty and Gourlet-Fleury 2006). Progress in reducing the impacts of forest resource harvesting or allowing concessions to be more productive and more sustainable is still dogged by gaps between theory and practice. A site manager, who is ultimately responsible for local infrastructure development and timber extraction, and who has reached his position through years of apprenticeship and on-the-job training, often has difficulty implementing suggestions that do not immediately appear to reduce costs or improve profit and translate into more complexities in organizing the work.

Large areas of tropical forest, irrespective of whether protected areas or controlled by communities, are still being harvested unsustainably, if not illegally, through logging, hunting, or collection of non-timber forest products. Part of the reason is that the legal frameworks are often antiquated, inadequate, underfunded, and poorly enforced. Corruption is generally widespread at all levels in natural resource management (Kolstad and 
Søreide 2009). For example, the legal framework in Cameroon allows logging companies to ignore some of the most harvested species in their forest management plans (Cerutti et al. 2008). As a result, much of the annual timber production is being realized as if no management rules apply. Because the government lacks the capacity to draw up management plans, something for which it is legally responsible, this task has been delegated to logging companies. Not surprisingly, under this arrangement, silvicultural elements and economic concerns take precedence over environmental and social ones.

Finally, many tropical forests, especially in Latin America, face increasing pressures of spontaneous colonization and conversion of forest to agricultural land (Geist et al. 2006). People in and around recently established reserves can face constraints on their use of resources and are contesting this, as are those who were displaced from their ancestral lands in the past (West et al. 2006, Adams and Hutton 2007, Agrawal and Redford 2009, and references therein). Some displacement continues, although the exact scale, cause, and consequences are fiercely debated (for example, see Schmidt-Soltau 2009, Curran et al. 2009). Some are using this discontent as camouflage for their own larger ambitions. In short, managing tropical forest reserves can be riven with conflict, disparate objectives, and lack of agreement on how best to move forward.

\section{GUIDELINES AND BEST PRACTICES}

In recent years, various international, regional, and national guidelines and tools have been developed on how to manage production forests in a more biodiversity-friendly manner, but the diversity of advice still makes it difficult for practitioners to decide just what to do (Dennis et al. 2008). Likewise, guidelines on best silvicultural and harvesting practices, which have also become widely available, are seldom adopted other than when formally required for certification. The voluntary nature of such guidelines means that managers usually choose to ignore them unless they are part of the concession contract. Many present guidelines are also little more than vague generalizations that do not clearly state how they should be implemented (Dennis et al. 2008). Site managers are looking for specific directives, and then only if these do not complicate or increase the costs of extraction. More explicit recommendations are needed, but the more precise they are, the narrower their area of applicability. Then again, with the proliferation of guidelines, it becomes difficult to determine which ones work and which do not. More research is needed to determine which guidelines are effective and under what circumstances. Finding the balance between the scope of complex management prescriptions and their usefulness is another outstanding task, one that will require closer cooperation between researchers, who may see the ideal, and managers, who have to work with what is practical.

Some guidelines pointing the way ahead are available (Frost et al. 2006, Meijaard et al. 2006, Gustafsson et al. 2007 and references therein). These emphasize building resilient, adaptable, joint social-ecological systems rather than trying to achieve stringent sustainability. The guidelines aim to consider the interests both of people and of forest resources, relying more on building partnerships and negotiating approaches and outcomes than on complex, often unrealistic, and unenforceable rules and regulations. In this mix of top-down and bottomup approaches, local knowledge is recognized, valued, and used. Management is intended to be adaptive, based on monitoring and evaluating the outcomes of actions, learning lessons, and applying them. Under such a scheme, management becomes site and circumstance specific, which is surely always superior to generic prescriptions.

Of course, expanding technical knowledge and approaches support this process. Forest management is being made easier and more precise through the adoption of new and powerful tools, including remote sensing and the use of geographic information systems (GIS). Most managed forests are now mapped in detail using a combination of remote and on-the-ground measurements. Research carried out over the past couple of decades has helped identify measures that can be undertaken to reduce the impact of logging (Putz et al. 2008). Advances in modeling, including the increasingly common use of Bayesian approaches, are also helping make sense of complex social-ecological problems, such as why some products are successfully commercialized whereas others are not, and what the potential impacts of different policy options might be on harvesters' livelihoods (Newton et al. 2006). 


\section{CHANGING LEGAL FRAMEWORKS}

Before 1992, legal frameworks for forest protection or management were largely restrictive and exclusionary. Following the Rio Earth Summit and the non-legally binding, authoritative Statement of Principles for a global consensus on the management, conservation, and sustainable development of all types of forests (United Nations 1992), the international dialog on forests required more holistic and participatory approaches in developing forest governance frameworks. These included the need to manage forest lands and resources sustainably to meet the social, economic, ecological, cultural, and spiritual needs of people now and in the future. Support for these principles has since been incorporated into international conventions such as the Convention on Biological Diversity (Expanded Programme of Work on Forest Biological Diversity) or the United Nation Forum on Forests (Non-Legally Binding Instrument on All Types of Forest).

International legal agreements and action plans have also been initiated to tackle illegal logging and improve governance, for example the Action Plan for Forest Law Enforcement, Governance, and Trade (FLEGT), the response of the European Union (EU) to the global problem of illegal logging and the international trade in illegally harvested timber. Producer countries can enter into voluntary partnership agreements with the EU to exclude illegal timber from their trade with the EU. Recent amendments (March 2008) to the Lacey Act in the USA likewise require importers of wood products, including manufactured products, to declare the species and source of the wood, to ensure that it does not have an illegal origin. The government can ban trade within, into, or out of the United States of any plants or plant products that have been sourced illegally. The provisions of the Act are currently being phased in (United States Department of Agriculture (USDA) 2009). In Africa, ministers from 32 African countries signed the African Forest Law Enforcement and Governance (AFLEG) declaration to, among other things, develop and implement appropriate management plans for all forests; encourage cooperation in the management of transboundary forest resources, including wildlife, as a means to curb illegal activity; ensure accountability and transparency in forest management; and develop participatory forest management practices to enhance forest law enforcement and governance (AFLEG 2003).
Many tropical countries are now revising their legal frameworks to give effect to some or all of these principles, policies, and measures. These include recognizing, in part, local people's rights to manage forests to meet diverse needs and to combat illegal logging. Schemes (e.g., FSC) for certifying management practices intended to promote, among other things, sustainable extraction of forest products, including timber, have become more widely accepted, as have complementary chain-ofcustody schemes for tracking the products from source to the user. Markets are increasingly valuing the forests for the goods and services that they provide (values in use), not just for what they are (non-monetary existence values).

Along with improvements in technical aspects have come important changes in the governance of tropical forests. The main foci of discussions between the North and the South, between the world of conservation and the world of development, have also shifted as new forms of governance, in which non-state entities are more heavily involved in forestry affairs, have gained ground. These changes have led others to view new potential management approaches - in particular, market-based instruments - as being opposed to conventional ones (cf. Karsenty 2004, Nasi and Guéneau 2007). In reality, both are needed (Wunder 2006).

Beyond changes in forest regulatory frameworks, changes in tenure are also coming (Rights and Resources Initiative (RRI) 2009). Many rural communities for whom forests have long been home but who lack title or other secure hold over the land are now been granted tenure, although more in response to larger forces driving decentralization and devolution than to changing management precepts and approaches (RRI 2009). A growing proportion of forests are now owned or managed (or both) by such communities, although disparities are still high across regions and among countries within regions.

\section{SOME LESSONS LEARNED}

\section{Broader Management Models are Needed for Tropical Production Forests}

We need more innovative models of tropical forest management, based on locally appropriate paradigms and application, in which the concept of sustainability is set in the broader context of 
managing tropical production forests. Although a viable network of protected areas is necessary for conserving some tropical forests and their biodiversity, it is surely insufficient. Issues of cost and practicality and the pressures of competing interests and land uses mean that the network can never be extensive enough to encompass all or even most of the biodiversity that needs protecting. Small geographic ranges and limited dispersal mean that populations isolated in reserves will be vulnerable to extinction, from chance events, let alone from unlawful hunting and extraction. This means that that the battle to conserve most tropical diversity will be won or lost in managed forests being used to produce timber and other goods. Even logged forest, managed appropriately, can provide habitat for otherwise threatened species (Clark et al. 2009).

Production forests, therefore, need to be managed for more than just timber production, but also for objectives such as supporting local livelihoods, biodiversity conservation, and environmental services, including carbon capture and storage. In some cases, management perspectives need to embrace the larger landscape, not be focused simply at the stand level. For conserving biodiversity, this may require thinking in terms of managing the landscape as a continuum of patches, corridors, and matrices, at a range of scales, rather than as a strongly differentiated patchwork at one scale (Fischer and Lindenmeyer 2006). For livelihoods, it means looking beyond agricultural land (often cultivated for only a short time before moving on) to the forests as a mosaic of: intact forest patches from which people obtain various goods and services, including sustenance in times of hardship; sacred groves, which remain untouched; ancient agroforests; land that may yet be cleared for settlement and cultivation; and patches regenerating after abandonment. Managing such complexity for both livelihoods and biodiversity conservation is still in its infancy (Pfund et al. 2008).

\section{Avoiding Irreversible Change Is More Relevant than Striving for Sustainability}

Trying to achieve "sustainability," however, is a noble but misplaced and ultimately unrealistic goal. No matter what actions are taken, forest composition and structure inevitably change with time, both in response to endogenous processes (e. g., forest succession) and external pressures (e.g., changes in rainfall and temperature regimes, human disturbances). Species respond to environmental change individually rather than synchronously as communities or ecosystems (see Davis and Shaw 2001 or Engelbrecht et al. 2007). Some species are lost or become rare (affecting usage) whereas new ecosystems emerge with new combinations of species, interactions, and properties. Relieving modern stressors, such as logging or hunting, will not necessarily result in these altered ecosystems reverting to their original state (O'Neill 1998, Hayashida 2005).

Instead, the aim should be to avoid irreversible change, especially deliberate or inadvertent conversion to non-forested land. Given that some change is inevitable, the aim should be to manage for resilience - the capacity of forest composition to change without any radical shift in overall structure and function. Uncertainty exists in all of this, especially in those systems or parts of systems that are driven by external forces of climate and human demand. Because of this, management needs to be flexible, taking into account new knowledge and understanding, changing circumstances, and based on learning lessons from present practices, both locally and elsewhere. The inextricable link between people and the environment must also be recognized and taken into account. No doubt, this all adds to the complexity of management, but decisions on action cannot be deferred. They have to be taken on best available information, with careful assessment of the potential costs and risks, and a commitment to monitoring and assessing outcomes, and learning and applying the lessons, where possible.

\section{Certification Needs Refining}

Certification of forest management practices is a major step forward in efforts to improve operations and the conditions under which they take place, but refinements are needed. More attention should be given to improving the efficiency of use of the materials being extracted, not simply focusing on reducing collateral damage, waste, and excessive extraction. At present, as little as $11 \%$ of the total volume of a tree being harvested ends up in usable form (Putz and Nasi 2009). The FSC criteria currently do not appear strong enough to drive improvements in efficiency along the companycontrolled processing chain. Extending the criteria under Principle 5, Benefits from the Forest, to address this deficiency would be an advance. 
The FSC's Principle 6, on environmental impact, is concerned almost entirely with identifying and managing on-site impacts. Managers and certifiers alike are not required to address those off-site impacts on people, biodiversity, and environmental services that are directly attributable to the operations being certified. Current schemes do not require formal risk assessment, measurable management objectives, obligatory monitoring, or corrective actions for conserving biodiversity (Wintle and Lindenmayer 2008), but rely instead on vague criteria, e.g. " 6.2 Safeguards shall exist which protect rare, threatened and endangered species and their habitats..." (FSC 1996). Provisions need to be made for identifying and managing adaptively the risks of both direct and indirect adverse impacts of forest management on biodiversity, on site and directly induced off site (Wintle and Lindenmayer 2008). Such provisions need to be extended also to specific environmental services (e.g., water yield and quality). Both measures might help to bring some science back into the process.

Certification itself is not an end, but a means toward achieving more efficient, equitable, and suitable management of forests, plantations, and associated resources. It may be a necessary instrument in some instances, but it is surely not sufficient to ensure the continued existence and productivity of most tropical forests. Among the supportive measures needed are greater commitment and investment by governments to tackle the incidence of illegal largescale commercial operations (Putz and Nasi 2009) and better incentives for forest users of all kinds to manage forests and forest resources more appropriately. Some of these incentives may come through payments for environmental services, others through the benefits of certification or other market-based instruments. These may include payments in exchange for reduced emissions from deforestation and forest degradation (REDD), an emerging prospect that is raising new expectations and challenges. However, if such incentives are not aligned with both authority and responsibility for managing resources, then management risks becoming dysfunctional (Murphree 2000).

\section{CONCLUSION}

So, despite improved treatment, is the patient still dying? The answer is, perhaps, "No, but it is surely suffering and will continue to do so until we work out how to moderate our demands." We must learn to adapt our management to the emerging new modified ecosystems we created and not only focus on so-called "natural" or near pristine systems. We should envision sustainable forest management as a co-evolutionary process among the changing forest, the changing market, and an industry moving toward higher efficiency standards over time. Our aim should be to maintain functional forest ecosystems that provide a continuous flow of goods and services for the benefit of everybody.

\section{Some Implications for Tropical Forestry Research}

Continuing to search for a globally accepted definition of sustainable forest management seems pointless. Even if we could agree on what we mean by "sustainable," and that is questionable, applying the concept and achieving the desired outcomes face many problems, as the papers in this special feature have shown. Trying to satisfy multiple and often disparate objectives, each with differing timeframes and spatial extents, is one complication. Attempting to accommodate varying environmental, economic, social, and political conditions, many of them outside the reach of forest management, is another. Some key influences on both forest productivity and human affairs, such as a region's geology and continental location, create background conditions that management cannot circumvent (Hammond and Zagt 2006).

Rather than aiming for an unattainable and contentious ideal, it may be more useful to strive for continuous improvement to achieve better outcomes when the best is unachievable. Such an approach would tailor both research and management to the relevant features of the environment and background conditions. Research could also be scaled more appropriately, taking into account more realistic local ecological and management timeframes and spatial extents. By looking for ongoing improvement in management, rather than holding to some distant and probably unattainable ideal, planners, managers, and researchers may be better placed to deliver more sustainable use of forest resources.

If nothing else, concerns about what it means to manage resources sustainably, and how, has sharpened focus on the need for trans-disciplinary training and research on the many factors affecting both forest composition and functioning, and the 
societal dynamics that will determine the future. This requires the transformation of forestry curricula to include courses designed not just to develop specialist skills, but also to promote a better understanding of context and how it predicates outcomes. It would also encourage a more outwardlooking, team-based approach to resolving complex social-ecological-economic problems in tropical forestry, fostering a more creative exchange of perspectives, ideas, and information among researchers in different fields.

To paraphrase Voltaire: we should not let the best become the enemy of the good.

Responses to this article can be read online at: http://www.ecologyandsociety.org/voll4/iss $2 /$ art40/ responses/

\section{Acknowledgments:}

Frank Katto of the Forest Stewardship Council kindly provided the latest figures for the areas of tropicalforests and plantations certified by the FSC. We also thank the two anonymous reviewers for their thoughtful comments and suggestions.

\section{LITERATURE CITED}

Adams, W.M., and J. Hutton. 2007. People, parks and poverty: political ecology and biodiversity conservation. Conservation and Society 5:147-183.

African Forest Law Enforcement and Governance (AFLEG). 2003. Ministerial Declaration on African Forest Law Enforcement and Governance (AFLEG). Yaoundé, Cameroon, 16 October 2003. [online] URL: http://siteresources.worldbank.org/IN TFORESTS/Resources/AFLEGMinisterialDeclara tion English.pdf.

Agrawal, A., and E. Ostrom. 2001. Collective action, property rights, and decentralization in resource use in India and Nepal. Politics and Society 29:485-514.

Agrawal, A., and K. Redford. 2009. Conservation and displacement: an overview. Conservation and Society 7:1-10.
Alden Wily, L. 2000. The evolution of communitybased forest management in Tanzania. Pages 127143 in Participatory Forest Management - A Strategy for Sustainable Forest Management in Africa. Proceedings of the International Workshop on Community Forestry in Africa, Banjul, The Gambia, 26-30 April 1999. UN Food and Agricultural Organization, Rome, Italy.

Amsallem, I., P. Koné, M. Wilkie, and M. Ngandji. 2004. Gestion forestière en Afrique centrale : à la recherche de l'excellence. Bois et Forêts des Tropiques 281:5-18

Azevedo-Ramos, C., B. Domingues Do Amaral, D. C. Nepstad, B. Soares Filho, and R. Nasi. 2006. Integrating ecosystem management, protected areas and mammal conservation in the Brazilian Amazon. Ecology and Society 11(2): 17. [online] URL: http: //www.ecologyandsociety.org/vol11/iss2/art17/.

Bowles, I. A., G. A. B. da Fonseca, R. A. Mittermeier, and R. E. Rice. 1998. Logging and tropical forest conservation. Science 280:18991900.

Bray, D. B., E. Duran, V. H. Ramos, J.-F. Mas, A. Velazquez, R. B. McNab,D. Barry, and J. Radachowsky. 2008. Tropical deforestation, community forests, and protected areas in the Maya Forest. Ecology and Society 13(2): 56. [online] URL: http://www.ecologyandsociety.org/vol13/iss2/ $\underline{\operatorname{art56/}}$.

Cerutti, P. O., R. Nasi, and L. Tacconi. 2008. Sustainable forest management in Cameroon needs more than approved forest management plans. Ecology and Society 13(2): 36. [online] URL: http: //www.ecologyandsociety.org/vol13/iss2/art36/.

Clark, C. J., J. R. Poulsen, R. Malonga, and P. W. Elkan, Jr. 2009. Logging concessions can extend the conservation estate for Central African tropical forests. Conservation Biology 23:12811293.

Curran, B., T. Sunderland, F. Maisels, J. Oates, S. Asaha, M. Balinga, L. Defo, A. Dunn, P. Telfer, L. Usongo, K. von Loebenstein, and P. Roth 2009. Are central Africa's protected areas displacing hundreds of thousands of rural poor? Conservation and Society 7(1): 30-45. 
Davis, M. B., and R. G. Shaw. 2001 Range shifts and adaptive responses to Quaternary climate change. Science 292 (5517):673-679.

Dennis, R. A., E. Meijaard, R. Nasi, and L. Gustafsson. 2008. Biodiversity conservation in Southeast Asian timber concessions: a critical evaluation of policy mechanisms and guidelines. Ecology and Society 13(1): 25. [online] URL: http: //www.ecologyandsociety.org/vol13/iss1/art25/.

Durst, P. B., C. Brown, H. D. Tacio, and M. Ishikawa, editors. 2005. In search of excellence: exemplary forest management in Asia and the Pacific. Food and Agriculture Organization of the United Nations, Regional Office for Asia and the Pacific, Regional Community Forestry Training Center for Asia and the Pacific, Bangkok, Thailand.

Engelbrecht, B. M. J., L. S. Comita, R. Condit, T. A. Kursar, M. T. Tyree, B. L. Turner, and S. P. Hubbell. 2007. Drought sensitivity shapes species distribution patterns in tropical forests. Nature 447:80-82.

Fischer, J., and D. B. Lindenmayer. 2006. Beyond fragmentation: the continuum model for fauna research and conservation in human-modified landscapes. Oikos 112:473-480.

Forest Stewardship Council (FSC). 1996. FSC international standard. FSC principles and criteria for forest stewardship. FSC-STD-01-001 (version 4-0) EN. Forest Stewardship Council, Bonn, Germany. [online] URL: http://www.fsc.org/filead $\mathrm{min} / \mathrm{web}$-data/public/document center/ international FSC policies/standards/ FSC STD 01001 V4 0 EN FSC Principles an d Criteria.pdf.

Forest Stewardship Council (FSC). 2009. Global FSC certificates: type and distribution. September 2009. Forest Stewardship Council, Bonn, Germany. [online] URL: http://www.fsc.org/fileadmin/web-data/ public/document center/powerpoints graphs/ facts figures/09-09-15 Global FSC certificates type and distribution - FINAL.pdf.

Fredericksen, T. S., and F. E. Putz. 2003. Silvicultural intensification for tropical forest conservation. Biodiversity and Conservation 12:1445-1453.
Frost, P., B. Campbell, G. Medina, and L. Usongo. 2006. Landscape-scale approaches for integrated natural resource management in tropical forest landscapes. Ecology and Society 11(2): 30. [online] URL: http://www.ecologyandsociety.org/voll1/ iss2/art30/.

Gardner, T. A., J. Barlow, R. Chazdon, C. A. Harvey, C. A. Peres, and N. S. Sodhi. 2009. Prospects for tropical forest biodiversity in a human-modified world. Ecology Letters 12:561582.

Geist, H., E. Lambin, C. Palm, and T.Tomich. 2006. Agricultural transitions at dryland and tropical forest margins: actors, scales and trade-offs. Environmental Policy 36:53-73.

Gong, P. 2002. Editorial-multiple-use forestry. Journal of Forest Economics 8:1-4.

Gustafsson, L., R. Nasi, N. H. Nghia, D. Sheil, E. Meijaard, D. Dykstra, H. Pryadi, and P. Q. Thu. 2007. Logging for the ark: improving the conservation value of production forests in SouthEast Asia. CIFOR Occasional Paper No. 48. CIFOR, Bogor, Indonesia.

Hammond, D. S., and R. J. Zagt. 2006. Considering background condition effects in tailoring tropical forest management systems for sustainability. Ecology and Society 11(1): 37. [online] URL: http://www.ecologyandsociety.org/voll1/ iss1/art37/.

Hayashida, F.M. 2005. Archaeology, ecological history, and conservation. Annual Review of Anthropology 34:43-65.

Hughes, T. P., D. R. Bellwood, C. Folke, R. S. Steneck, and J. Wilson. 2005. New paradigms for supporting the resilience of marine ecosystems. TRENDS in Ecology and Evolution 20:380-386.

International Tropical Timber Organization (ITTO). 2006. Status of tropical forest management 2005. ITTO Technical Series No. 24. Yokohama, Japan.

Kant, S. 2004. Economics of sustainable forest management. Forest Policy and Economics 6: 197203. 
Karsenty, A. 2004. Des rentes contre le développement? Les nouveaux instruments d'acquisition mondiale de la biodiversité et l'utilisation des terres dans les pays tropicaux. Mondes en développement 127(3):1-9.

Karsenty, A., and S. Gourlet-Fleury. 2006. Assessing sustainability of logging practices in the Congo Basin's managed forests: the issue of commercial species recovery. Ecology and Society 11(1): 26. [online] URL: http://www.ecologyandso ciety.org/vol11/iss1/art26/.

Kolstad, I., and T. Søreide. 2009. Corruption in natural resource management: implications for policymakers. Resources Policy 34:214-226.

Laumonier, Y., R. Bourgeois, and J.-L. Pfund. 2008. Accounting for the ecological dimension in participatory research and development: lessons learned from Indonesia and Madagascar. Ecology and Society 13(1): 15. [online] URL: http://www.e cologyandsociety.org/vol13/iss1/art15/.

López-Hoffman, L., I. E. Monroe, E. Narvàez, M. Martìnez-Ramos, and D. D. Ackerly. 2006. Sustainability of mangrove harvesting: how do harvesters' perceptions differ from ecological analysis? Ecology and Society 11(2): 14. [online] URL: http://www.ecologyandsociety.org/vol11/iss2/ art14/.

Lugo, A. E. 1999. Will concern for biodiversity spell doom to tropical forest management? Science of the Total Environment 240:123-131.

Meijaard, E., D. Sheil, R. Nasi, and S. A. Stanley. 2006. Wildlife conservation in Bornean timber concessions. Ecologyand Society 11(1): 47. [online] URL: http://www.ecologyandsociety.org/vol11/iss1/ art47/.

Michon, G., H. De Foresta, P. Levang, and F. Verdeaux. 2007. Domestic forests: a new paradigm for integrating local communities' forestry into tropical forest science. Ecology and Society 12(2): 1. [online] URL: http://www.ecologyandsociety.org/ vol12/iss2/art1/.

Murphree, M. W. 2000. Boundaries and borders: the question of scale in the theory and practices of common property management. Eighth Biennial Conference of the International Association for the Study of Common Property, 31 May-4 June 2000.
Bloomington, Indiana, USA.

Nasi, R., and S. Guéneau. 2007. Les changements en forêt tropicale: vers de nouvelles formes de gouvernance. Revue Forestière Française LIX (5):524-536

Nasi R., D. Brown, D. Wilkie, E. Bennett, C. Tutin, G. van Tol, and T. Christophersen. 2008. Conservation and use of wildlife based resources: the bushmeat crisis. CBD Technical Series No. 33. Secretariat of the Convention on Biological Diversity, Montreal, Quebec, Canada.

Newton, A. C., E. Marshall, K. Schreckenberg, D. Golicher, D. W. te Velde, F. Edouard, and E. Arancibia. 2006. Use of a Bayesian belief network to predict the impacts of commercializing nontimber forest products on livelihoods. Ecology and Society 11(2): 24. [online] URL: http://www.ecolog yandsociety.org/vol11/iss2/art24/.

O’Neill, R. V. 1998. Recovery in complex ecosystems. Journal of Aquatic Ecosystems Stress and Recovery 6:181-187.

Pearce, D., F. J. Putz, and J. K. Vanclay. 2003. Sustainable forestry in the tropics: panacea or folly? Forest Ecology and Management 172:229-247.

Pfund, J.-L., P. Koponen, T. O'Connor, J.-M. Boffa, M. van Noordwijk, and J.-P. Sorg. 2008. Biodiversity conservation and sustainable livelihoods in tropical forest landscapes. Pages 297-322 in R. Lafortezza, J. Chen, G. Sanesi, and T. R. Crow, editors. Patterns and processes inforest landscapes. Multiple use and sustainable management. Springer, Berlin, Germany.

Poffenberger, M., editor. 2001. Communities and forest management in South Africa. International Union for the Conservation of Nature, Gland, Switzerland.

Poore, D., J. Burgess, J. Palmer, S. Rietbergen, and T. Synott. 1989. No timber without trees: sustainability in the tropical forests. Earthscan, London, UK.

Putz, F. E., and R. Nasi. 2009. Carbon benefits from avoiding and repairing forest degradation. In A. Angelsen, editor. Realising REDD: national strategies and policy options. CIFOR, Bogor, Indonesia, in press. 
Putz, F. E., P. Sist, T. Fredericksen, and D. Dykstra. 2008. Reduced-impact logging: challenges and opportunities. Forest Ecology and Management 256:1427-1433.

Ravindranath, N. H., and P. Sudha. 2004. Joint forest management in India: spread, performance and impact. Universities Press (India), Hyderabad, India.

Rice, R. E., R. E. Gullison, and J. W. Reid. 1997. Can sustainable management save tropical forests? Scientific American 276:44-49.

Rights and Resources Initiative (RRI). 2009. Tropical forest tenure assessment: trends, challenges and opportunities. Report for the Rights and Resources Initiative and the International Tropical Timber Organization.

Robichaud, W. G., A.R.E. Sinclair, N. OdarkorLanquaye, and B. Klinkenberg. 2009. Stable forest cover under increasing populations of swidden cultivators in central Laos: the roles of intrinsic culture and extrinsic wildlife trade. Ecology and Society 14(1): 33. [online] URL: http: //www.ecologyandsociety.org/vol14/iss1/art33/.

Rodrigues, A. S. L., H. R. Akçakaya, S. J. Andelman, M. I. Bakarr, L. Boitani, T. M. Brooks, J. S. Chanson, L. D. C. Fishpool, G. A. B. Da Fonseca, K. J. Gaston, M. Hoffmann, P. A. Marquet, J. D. Pilgrim, R. L. Pressey, J. Schipper, W. Sechrest, S. N. Stuart, L. G. Underhill, R. W. Waller, M. E. J. Watts, and X. Yan. 2004. Global gap analysis: priority regions for expanding the global protected-area network. BioScience 54:10921100 .

Schmidt-Soltau, S. 2009. Is the displacement of people from parks only "purported," or is it real? Conservation and Society 7(1):46-55.

Schmitt, C. B., N. D. Burgess, L. Coad, A. Belokurov, C. Besançon, L. Boisrobert, A. Campbell, L. Fish, D. Gliddon, K. Humphries, V. Kapos, C. Loucks, I. Lysenko, L. Miles, C. Mills, S. Minnemeyer, T. Pistorius, C. Ravilious, M. Steininger, and G. Winkel. 2009. Global analysis of the protection status of the world's forests. Biological Conservation 142:2122-2130.
Schulze, M., J. Grogan, and E. Vidal. 2008. Forest certification in Amazonia: standards matter. Oryx 42:229-239.

Steen, H. K., editor. 1984. History of sustainedyield forestry: a symposium. Forest History Society, Durham, North Carolina, USA.

United Nations. 1992. Non-legally binding authoritative statement of principles for a global consensus on the management, conservation and sustainable development of all types of forests. Annex III. Report of the United Nations Conference on Environment and Development, Rio de Janeiro, 3-14 June 1992. A/CONF.151/26, volume III. United Nations, New York, New York, USA. [online] URL: http://www.un.org/documents/ga/co nf151/aconf15126-3annex3.htm)

United States Department of Agriculture (USDA). 2009. Newsroom: Lacey Act. USDA, Animal and Plant Health Inspection Service (APHIS) website. [online] URL: http://www.aphis. usda.gov/newsroom/hot issues/lacey act/index.shtml

Upton, C. , and S. Bass. 1995. The forest certification handbook. Earthscan, London, UK.

West, P., J. Igoe, and D. Brockington. 2006. Parks and people: the social impact of protected areas. Annual Review of Anthropology 35:251-277.

Wilkie, D., J. F. Carpenter, and Q. Zhang. 2001. The under-financing of protected areas in the Congo Basin: so many parks and so little willingness-topay. Biodiversity and Conservation 10:691-709.

Wintle, B. A., and D. B. Lindenmayer. 2008. Adaptive risk management for certifiably sustainable forest management. Forest Ecology and Management 256:1311-1319.

Wood, D. 1995. Conserved to death: Are tropical forests being overprotected from people? Land Use Policy 12:115-135.

Wunder, S. 2006. Are direct payments for environmental services spelling doom for sustainable forest management in the tropics? Ecology and Society 11(2): 23. [online] URL: http: //www.ecologyandsociety.org/vol11/iss2/art23/. 
Wunder, S., B. Campbell, P. G. H. Frost, J. A. Sayer, R. Iwan, and L. Wollenberg. 2008. When donors get cold feet: the community conservation concession in Setulang (Kalimantan, Indonesia) that never happened. Ecology and Society 13(1): 12. [online] URL: http://www.ecologyandsociety.org/voll3/ iss1/art12/. 